\title{
Atomoxetine associated red ear: A case report
}

\author{
Atomoksetin ilişkili kırmızı kulak: Olgu sunumu
}

\author{
Hande Ayraler Taner 1 , Burcu Akın Sari ${ }^{2}$ \\ ${ }^{1}$ Assis. Prof., ${ }^{2}$ Assoc.Prof., Baskent University Faculty of Medicine, Child and Adolescent Psychiatry Department, Ankara, Turkey \\ https://orcid.org/0000-0003-2106-7928-https://orcid.org/0000-0002-9730-7206
}

\section{SUMMARY}

Red ear syndrome is defined as mostly unilateral burning pain and redness of external ear. It has two forms idiopathic and secondary. Idiopathic red ear syndrome is mostly seen in young people and associated with migraine. Secondary red ear syndrome is more frequent in adults and releated with cervical disorder. Our patient was a 10 year old boy diagnosed with attention deficit hyperactivity disorder (ADHD) and spesific learning disorder. He had a complaint of redness in his ear, following the atomoxetine treatment for ADHD. The redness was appearing after taking atomoxetine in 1 hour. The redness in his ear was unilateral and lasted in 4 hours. Sometimes headaches were accompanied with red ear. After atomoxetine treatment was ceased the redness and the headache in his ear were dissappered. In the pathophysiology of red ear sydrome there is a disregulation of sympathic outflow. Atomoxetine has a high selectivity for noradrenergic receptors and also has an effect on periferic noradrenergic receptors. Atomoxetine could change the sympathic vasodilation/vasoconstruction balance and cause red ear. Although the red ear is not a life threating situation, it could cause discomfort and anxiety, so the clinicians should keep in mind red ear syndrome while using atomoxetine. To our best knowledge this is the first red ear case associated with atomoxetinein literature.

Key Words: Atomoxetine, attention deficit hyperactivity disorder, side effect

(Turkish J Clinical Psychiatry 2020;23:232-235)

DOI: $10.5505 / \mathrm{kpd} .2020 .49932$

\section{ÖZET}

Kırmızı kulak sendromu çoğunlukla tek taraflı yanıcı ağrı ve dış kulağın kızarıklığı ile giden bir durumdur. İdiopatik ve ikincil olmak üzere iki formu vardır. İdiopatik kırmızı kulak sendromu daha çok gençlerde ve migren ile ilişkili olarak, erişkinlerde ise servikal bozukluklarla ile ilgili olabilir. Bu olgu sunumunda dikkat eksikliği hiperaktivite bozukluğu ( $D E H B$ ) ve özgül öğrenme güçlüğü tanıları bulunan bir 10 yaşında bir erkek hasta sunmaktayız. Hastaya DEHB tedavisine yönelik olarak atomoksetin başlandıktan sonra hastada kulağında kzıarıklık yakınması başladı. Kızarıklık atomoksetin alımını takiben bir saat içinde oluyordu. Kulağındaki kızarıklık tek taraflı oluyor ve 4 saat içinde kayboluyordu. Bazen kızarıklığa başağrısının da eşlik ettiğini belirtiyordu. Atomoksetin kesildikten sonra hastanın kulağındaki kızarıklık ve başağrısı kayboldu. Kırmızı kulağın patofizyolojisinde sempatik desarj disregülesyonu bulunmaktadır.Atomoksetin noradrenerjik reseptörlere karşı yüksek seçiciliği bulunan ve periferik noradrenerjik reseptörler üzerine de etkisi olan bir moleküldür. Atomoksetin sempatik vazodilatasyon / vazokonstrüksiyon dengesini bozarak kırmızı kulağa sebebp olabilir. Atomoksetin ilişkili kırmızı kulak hayatı tehdit edici bir druum olmamakla birlikte rahatsızlık ve kaygıya sebep olabilir. Bu sebeple klinisyenler atomoksetin kullanırken bu durumu akıllarında tutmalıdırlar. Bu olgu sunumu literatürdebulunan ilk atomoksetin ilişkili kırmızı kulak vakasıdır.

Anahtar Sözcükler: Atomoksetin, dikkat eksikliği hiperaktivite bozukluğu, yan etki 


\section{INTRODUCTION}

Methylphenidate, amphetamine salts and atomoxetine can be used in the treatment of ADHD (1). Atomoxetine is a selective presynaptic dopamine reuptake inhibitor in the prefrontal cortex (2). Red ear syndrome ( RES) described as mostly unilateral episodes of burning pain and redness of the external ear, $31 \%$ of the cases defined as bilateral. In most of the cases, the only associated symptoms are redness and the warmth of the ear (3). RES is also defined as a rare headache disorder. It has two identified forms: idiopathic and secondary. Idiopathic RES mostly seen in young people and associated with migraine, secondary RES is more frequent in adults and related with cervical disorders (4). Early onset red ear syndrome is mostly occurs with stress, temperature changes, rubbing and touching (5). In clinical trials with atomoxetine it had been reported rashes and Raynaud's phenomenon in children and adolescents, hot flushes in adults, but there was no reported red ear case $(6,7,8)$. In this case report we present a red ear case associated with atomoxetine.

\section{CASE}

10 year old boy diagnosed with ADHD and dyslexia. He had no hyperactivity but he had forgetfulness, losing things. He never wants to study at home and has conflicts with his parents. He usually seems not to listen when someone directly speaks to him. Also he usually seems disorganized and untidy, he has difficulty in finding things that he needs at school. He is distracted quickly and he makes careless mistakes at school and exams. $\mathrm{He}$ also has difficulty in following directions. He was born prematurely. His motor development was in time but his speech development was delayed. $\mathrm{He}$ had dysgraphia, in his writing he had missing letters, he also had difficulty in reading, rythmic counting and mathematics. His WISC-R (Wechsler Intelligence Scale for Children Revised Form) verbal subtests score was 95 ,performance subtest: 114, total score was: 104 . He had 1 (one) point from Conner's Teachers Rating Scale hyperactivity subscale, had 17 points from inattention subscale and had 1 (one) point from oppositional subscale. He was diagnosed with ADHD and spe- cific learning disorder according to the DSM V criteria. His height was $134 \mathrm{~cm}$ (\%50-25 percentile) and his weight was 38 kilos (\% 75percentile). His systolic blood pressure was $100 \mathrm{~mm} \mathrm{Hg}$ and diastolic blood pressure was $60 \mathrm{~mm} \mathrm{Hg}$. His pulse was 100per minute. With this diagnosis we prescribed atomoxetine $18 \mathrm{mg}$ and $25 \mathrm{mg}$ capsules. In thefirst 2 weeks of treatment, he used $18 \mathrm{mg} /$ day atomoxetine and then we increased the dosage $43 \mathrm{mg}$ per day. The complaint of redness in his ears began with the first dose of atomoxetine and worsened after increasing the dosage to $43 \mathrm{mg} /$ day. Redness in his ear appeared about 60 or 90 minutes after oral ingestion of atomoxetine and sometimes had been spreading to neck and accompanied by headaches on his frontal region. He hadn't had lacrimation with the redness on his ear. Redness had lasted about 4 hours and was unilateral, but the side was variable. He didn't describe any other trigger except atomoxetine. In his physical examination after taking $43 \mathrm{mg}$ per day atomoxetine for 4 weeks; his systolic blood pressure was $90 \mathrm{~mm} \mathrm{Hg}$ and diastolic blood pressure was $60 \mathrm{~mm} \mathrm{Hg}$. His pulse was 111 per minute, and there was no abnormality in his electrocardiography. He was very anxious and feeling uncomfortable with the redness of his ear and the sense of burning pain. He was reluctant to take atomoxetine.With these complaints we reduced the atomoxetine dosage to $25 \mathrm{mg}$ /day but the redness on his ear still remained. He didn't have a family history of red ear. He didn't have a history of Herpes Zoster.He used $25 \mathrm{mg}$ per day atomoxetine for 2 weeks, but there was no change in his complaints. We decided to stop atomoxetine. The day he stopped taking atomoxetine the complaint of redness in his ear ended. We started $18 \mathrm{mg}$ per day long release methylphenidate. We increased the dose follow-up. Now he is on methylphenidate for 3 years and had no complaint of redness on his ear after we have stopped atomoxetine.

\section{DISCUSSION}

The red ear syndrome first described by Lance 1994 (9). It's mostly unilateral and side locked and it's pain mostly described as a burning sensation and generally lasts in 30-60 minutes. Secondary RES is associated with servical spinal lesions and temporomandibular joint dysfunction (3). In our 
case the redness of the ear had begun after taking atomoxetine. It lasts in 4 hours and side locked. Our patient had no history of trauma and the complaint started with atomoxetine. We have ruled out the out secondary RES. Our patient also didn't have a history of Herpes Zoster. All of the complaints about the red ear are disappeared after we stopped atomoxetine. Raieli et al investigated the red ear syndrome in juvenile primary headaches and showed that RES is a specific sign of a migraine and it could be associated with parasympathetic related migraine features (10). Although in our case the red ear sometimes accompanied by a headache, we ruled out a migraine in our case, because he didn't have any headaches before and after atomoxetine. We also ruled out allergies, because the redness in the ear is unilateral didn't accompanied with itching. With all these knowledges in mind; our case is a secondary red ear syndrome associated with atomoxetine. According to the WHO-UMC ( World Health OrganizationUppsala Monitoring Center) causality categories it is a "probable/likely" adverse event (11).

Although the mechanism of RES is not clarified; it could be associated with dysregulation of sympathetic outlow (12). The ear lobe and the external autidory canal are innervated from $\mathrm{C} 2$ and $\mathrm{C} 3$ roots. The third branch of trigeminal nerve gives a branch called auriculo temporal nerve where the tragus and the anterosuperior aspect of ear is innervated. The blood vessels of the ear lobe come from the external carotid artery, and they are supplied by the sensory fibers of trigeminal nerve (13) . The redness of the ear could be a result of an activation of sympathetic vasodilatation or the inhibition of sympathetic vasoconstruction (12). Atomoxetine has a higher selectivity for norepinephrine (NE) transporters and lower selectivity for serotonine(5-HT) and dopamine ( DA) transporters (14). Atomoxetine also has effects on peçlşşoriferic noradrenergic receptors $(15,16)$. By effecting the periferic noradrenergic receptors, we could hypothesize that atomoxetin could change sympathic vasodilatation/ sympathic vasoconstruction balance, this situation could be resulted with redness of the ear.

The red ear syndrome doesn't have a clarified treatment strategy; but non-steroidal anti-inflam- matory drugs, anti-depressants (tricyclic antidepressants and paroxetine), beta blockers, calcium channel blockers, methysergide, sumatriptan, antiepileptic drugs (gabapentin, pregabalin, topiramate, valproic acid) and topical lidocaine and steroidal applicational could be used inthe treatment of red ear syndrome $(3,13,17,18,19)$. Even though the red ear syndrome is not a life treating situation, but it gives discomfort to the patient and could cause anxiety. In our case we decided to stop atomoxetine because our patient didn't benefit enough and didn't want to use atomoxetine because of the redness on his ears. The possibility of red ear syndrome with atomoxetine should be kept in mind and if necessary additional treatment or medication changes should be an option.

Correspondence address: Assis. Prof. Hande Ayraler Taner, Baskent University Faculty of Medicine, Child and Adolescent Psychiatry Department, Ankara, Turkey h_ayraler@hotmail.com 


\section{REFERENCES}

1. Thapar A, Cooper M. Attention deficit hyperactivity disorder. Lancet [Internet]. 2016;387(10024):1240-50.

2. Garnock-Jones KP, Keating GM. Atomoxetine. Pediatr Drugs. 2009;11:203-26.

3. Lambru G, Miller S, Matharu MS. The red ear syndrome. J Headache Pain. 2013;14:83.

4. Ryan S, Wakerley BR, Davies P. Red ear syndrome: a review of all published cases (1996-2010). Cephalalgia. 2013;33:190201.

5. Wollina U. Three orphans one should know: red scalp, red ear and red scrotum syndrome. J Eur Acad Dermatology Venereol. 2016;11:e169-70.

6. Gökçen C, Kutuk MO, Coşkun Ş. Dose-Dependent Raynaud's Phenomenon Developing from Use of Atomoxetine in a Girl. J Child Adolesc Psychopharmacol. 2013;23:428-30.

7. Gülle ZN, Karayagmurlu A, Coskun M. Raynaud's Phenomenon Related with Atomoxetine Treatment in a Child with Autism and Attention-Deficit/Hyperactivity Disorder. J Child Adolesc Psychopharmacol. 2019 Published Online:2 Jul 2019 https://doi.org/10.1089/cap.2019.0025

8. Eli Lilly and Company.Highlights of Prescribing Information. p. 1-18. https://pi.lilly.com/us/strattera-pi.pdf Accessed on: July 24,2019

9. Lance JW. The mystery of one red ear. Clin Exp Neurol. 1994;31:13-8.

10. Raieli V, Compagno A, Brighina F, Franca G La, Puma D, Ragusa D, et al. Prevalence of red ear syndrome in juvenile primary headaches. Cephalalgia. 2011;31:597-602.

11. The Uppsala Monitoring Centre. The use of the WHOUMC system for standardised casecausalityassesment.http://www.who.int/medicines/areas/qua lity_safety/safety_efficacy/WHOcausality_assessment.pdf Accessed on: July 24, 2019

12. Kumar N, Swanson JW. The 'red ear syndrome'revisited: two cases and a review of literature. Cephalalgia. 2004;24:305-8.

13. Flicinski J, Wigowska-Sowinska J, Winczewska-Wiktor A, Steinborn B. Red ear syndrome-Case report and review of literature. Neurol Neurochir Pol. 2015;49:74-7.

14. Bymaster FP, Katner JS, Nelson DL, Hemrick-Luecke SK, Threlkeld PG, Heiligenstein JH, et al. Atomoxetine increases extracellular levels of norepinephrine and dopamine in prefrontal cortex of rat: a potential mechanism for efficacy in attention deficit/hyperactivity disorder. Neuropsychopharmacology. 2002;27:699.

15. Mirbolooki MR, Upadhyay SK, Constantinescu CC, Pan ML, Mukherjee J. Adrenergic pathway activation enhances brown adipose tissue metabolism: A [18 F] FDG PET/CT study in mice. Nucl Med Biol. 2014;41:10-6.

16. Bilgiç Ö, Bilgiç A. Possible atomoxetine-induced vitiligo: a case report. ADHD Atten Deficit Hyperact Disord. 2015;7:17981.

17. Raieli V, Compagno A, D'Amelio M. Red Ear Syndrome. Curr Pain Headache Rep. 2016;20:19.
18. Coleman J, Ream MA. A Boy With Red Ears. Semin Pediatr Neurol. 2018;26:92-3.

19. Hernández CR, Loza SM, López RL, Romero M del MG. Red Ear Syndrome in a Pediatric Patient. Pediatr Emerg Care. 2018;34:e199-200. 